НОВІ ПРОФЕСІЙНІ РОЛІ ВЧИТЕЛЯ

В УМОВАХ НОВОї УКРАЇНСЬКОÏ ШКОЛИ

\title{
NEW PROFESSIONAL ROLES OF TEACHER IN THE CONDITIONS OF THE NEW UKRAINIAN SCHOOL
}

У статті розкрито суть та особливості нових просресійних ролей вчителя в Новій українській школі. Обгрунтовано необхідність організації перепідготовки вчителівпрактиків та оновлення фрахової підготовки майбутніх учителів до реалізації цих ролей. Потребують удосконалення зміст, форми й методи срахової підготовки студентів у аспекті фрормування їхньої здатності до реалізації нових професійних ролей в Новій українській школі.

Цілі статmі: проаналізувати теоретичні основи нових профресійних ролей учителя в умовах Нової української школи, з'ясувати ставлення вчителів до нових просресійних ролей учителя та готовність їх виконувати, проаналізувати досвід орахової підготовки майбутніх учителів початкової школи в Національному університеті «Чернігівський колегіум» імені Т.Г. Шевченка до реалізації нових профресійних ролей.

Згідно 3 компетентнісним й особистісно орієнтованим підходами в Новій українській школі змінюються фрункції вчителя, що зумовлюють реалізацію ним нових просресійних ролей фрасилітатора, модератора, тьютора, коуча.

Проведене анкетування вчителів почат кових класів свідчить про обізнаність більшості (80\%) з нормативно-правовою базою організації освітнього процесу в Новій українській школі. Однак 20\% з опитаних учителів відчувають трудноші під час складання робочих програм, реалізації компетентнісного підходу в навчанні, під час планування й організації дослідницької, самостійної та творчої діяльності учнів. 30\% з них відчувають труднощі у використанні нових професійних ролей в умовах Нової української школи. Інші опитані вчителі (70\%) таких трудношів не відчувають і зазначають, що й раніше виконували більшість з перерахованих ролей, оскільки переконані, що головне завдання сучасного вчителя - не дати дітям знання в готовому вигляді, а організувати їхню активну самостійну навчально-пізнавальну діяльність, організувати навчання під час активної діяльності, створити умови для самостійного вирішення учнями дослідницьких завдань.

УДК 373.3.091.12.011.3-051 DOI https://doi.org/10.32843/2663-60852019-15-2-18

\section{Лимар Ю.М.}

канд. пед. наук,

доцент кафедри дошкільної

та початкової освіти

Національного університету

«Чернігівський колегіум»

імені Т.Г. Шевченка

Чекан Ю.М.,

студентка магістратури

факультету дошкільної,

початкової освіти і мистецтв

Національного університету

«Чернігівський колегіум»

імені Т.Г. Шевченка здатності виконувати ці професійні ролі в процесі квазіпрофесійної діяльності на практичних заняттях, набувають досвіду їх реалізації під час проходження різних видів педагогічної практики.

Ключові слова: Нова українська школа, професійні ролі вчителя, фрасилітатор, тьютор, партнер, коуч, модератор.

In the article essence and features of new professional roles of teacher are exposed at New Ukrainian school. The necessity of organization of retraining of practical teachers-workers and updating of professional preparation of future teachers is reasonable to realization of these roles. In particular maintenance, forms and methods of professional preparation of students, need an improvement in the aspect of forming of their capacity for realization of new professional roles in New Ukrainian school.

Whole articles: 1) to analyse theoretical bases of new professional roles of teacher in the conditions of New Ukrainian school, 2) to find out attitude of teachers toward the new professional roles of teacher and readiness to execute them; 3) to analyze the experience of professional preparation of future elementary school teachers at Taras Shevchenko "Chernihiv Collegium" National University for realization of new professional roles.

In accordance with the competence and personality-oriented approaches in the New Ukrainian school, the functions of the teacher change, which causes him to realize new professional roles, such as: facilitator, moderator, tutor, coach. The conducted questionnaire survey of primary school teachers indicates that the overwhelming majority (80\%) is aware of the legal framework for organizing the educational process in the New Ukrainian school. However, $20 \%$ of the surveyed teachers experience difficulties in compiling work programs, implementation of the competence approach in training, planning and organization of students' research, independent and creative activity. $30 \%$ of them have difficulty in using new professional roles in the context of New Ukrainian school. The rest (70\%) do not experience such difficulties and note that most of the above roles have been fulfilled before, as they are convinced that the main task of the modern teacher is not to give children ready knowledge, but to organize their active independent educational and cognitive activity, to organize training in the process of active activity, to create conditions for students to solve research problems independently.

The experience of professional preparation of future elementary school teachers at the Taras Shevchenko "Chernihiv Collegium" National University for realization of new professional roles is analyzed. It is carried out taking into account the main tendencies of education reform, new approaches, methods, technologies of the New Ukrainian School. It is carried out taking into account the main tendencies of education reform, new approaches, methods, technologies of the New Ukrainian School. Thus, educational programs of pedagogical disciplines and professional methods, subjects of course and qualification works, programs of qualifying exams, 
programs of pedagogical practices have been updated in accordance with the main tendencies of New Ukrainian school. Considerable attention is also given to preparing future teachers to perform various professional roles in primary school. Students analyze the nature and features of new professional teacher roles, acquire the ability to fulfill these professional roles in the course of quasi-professional activity in practical classes, gain experience in their implementation during various types of pedagogical practice.

Key words: New Ukrainian school, professional teacher roles, facilitator, tutor, partner, coach, moderator.
Постановка проблеми у загальному вигляді. Сьогодні суспільство висуває нові вимоги до професійних ролей педагога. Сучасний учитель втратив свою фрункцію основного джерела знань, організатора репродуктивного навчання учнів. Натомість від нього чекають організації взаємодії з учнями на засадах партнерства, поваги, врахування індивідуальних особливостей учнів, створення умов для розкриття їхнього потенціалу, використання сучасних технологій навчання, ініціативності, творчого підходу.

Аналіз останніх досліджень і публікацій. Роль учителя по-різному визначалася в кожну конкретну історичну епоху згідно з прийнятими тоді педагогічними концепціями. Так, представники гуманістичного напряму в педагогіці (А. Дістервег, Я. Коменський, Й. Песталоцці, Ж.-Ж. Руссо, В. Сухомлинський, К. Ушинський) розглядали вчителя як носія й транслятора культурних цінностей від старшого до молодшого покоління. Проголошувалися принципи поваги до особистості учня, переважання діалогічних фрорм навчання, довіри та емоційної близькості вчителя й учнів.

Сучасними вченими (Н. Бібік, І. Дичківською, В. Моляко, О. Савченко та іншими) розроблено теоретичні основи готовності вчителів до використання нових професійних ролей.

Виділення не вирішених раніше частин загальної проблеми. Аналіз нормативних документів, наукових досліджень та досвіду роботи вчителів щодо особливостей роботи вчителя в Новій українській школі (далі - НУШ) свідчить про необхідність здійснення досліджень, спрямованих на організацію перепідготовки вчителів-практиків та оновлення фрахової підготовки майбутніх учителів до реалізації нових професійних ролей. Потребують удосконалення зміст, форми й методи фрахової підготовки студентів у аспекті фрормування їхньої здатності до реалізації нових професійних ролей в НУШ.

Мета статті складається з таких частин: 1) проаналізувати теоретичні основи нових професійних ролей учителя в умовах НУШ; 2) з'ясувати ставлення вчителів до нових професійних ролей учителя та готовність їх виконувати; 3) проаналізувати досвід фрахової підготовки майбутніх учителів початкової школи в Національному університеті «Чернігівський колегіум» імені Т. Г. Шевченка до реалізації нових професійних ролей.

Виклад основного матеріалу дослідження. Учитель відіграє значну роль у орормуванні нового, інорормаційного типу суспільства, тому він повинен бути прикладом у постійному прагненні до оновлення знань, в оволодінні передовими технологіями, розвитку свого творчого, гуманітарного мислення. Будучи одним з кращих представників української інтелігенції, вчитель повинен поєднувати в собі не тільки глибокі знання і професіоналізм в галузі викладання предмета, але й моральну чистоту, високу загальну культуру, соціальну толерантність, стриманість у поведінці та судженнях [1].

Учитель в умовах НУШ здійснює такі ффункції: $\epsilon$ джерелом знань для учнів як під час уроків, так і в позаурочній діяльності, забезпечує охорону життя і зміцнення здоров'я дітей, виконує управлінську фрункцію, організовує освітню діяльність учнів, створює педагогічні умови для успішного навчання, розвитку та виховання дітей, здійснює педагогічну освіту батьків, регулювання та узгодження виховних впливів сім'ї та школи, виконує фрункцію класного керівника [8, с. 23].

Реалізація цих функцій пов'язана з виконанням нових професійних ролей вчителем. Роль учителя - це сукупність нормативно схвалених приписів (вимог), що пред'являються до професійної поведінки педагогічного працівника, яка контролюється уявленням його самого і оточення про цю роль, про необхідні дії в конкретній педагогічній ситуації [3].

Реалізація педагогіки партнерства, компетентнісного та особистісно орієнтованого підходів у НУШ зумовлює реалізацію вчителем нових профресійних ролей фрасилітатора, тьютора, коуча, модератора.

Розглянемо детальніше кожну з наведених вище профресійних ролей учителя в умовах НУШ [6].

Фасилітатор (від англ. "facilitate" - сприяння, допомога, полегшення) - це вчитель, який стимулює, направляє процес самостійного пошуку інфрормації та спільної діяльності учнів. Учительфрасилітатор організовує ефективне спілкування, обмін думками, вироблення спільного рішення всіх учасників обговорення, займаючи нейтральну позицію.

Тьютор (від англ. tutor - учитель) - особа, що веде індивідуальні або групові заняття з учнями, студентами, репетитор, наставник, опікун. На думку науковців, тьютор працює за допомогою питань, а звичайний вчитель - відповідей [6]. Така роль учителя важлива під час дистанційного на інклюзивного навчання.

Коуч (від англ. coaching - тренерство) - це не просто роль, а профессія, призначення якої - 
сприяти учням в досягненні їхніх життєвих цілей, розвитку та успіху [7].

Модератор (від англ. moderator - регулятор, посередник) - особа, яка організовує групову роботу, активізує й регламентує процес взаємодії учасників групи на основі демократичних принципів, забезпечує ділове спілкування, протоколювання процесу обговорення, проміжних і підсумкових результатів групової дискусії [7].

Для виявлення ставлення вчителів початкових класів до нових професійних ролей учителя в Новій українській школі, а також готовності їх виконувати було проведено анкетування й бесіди з учителями Київської школи I ступеня № 6 та Чернігівського 33СО № 29. В опитуванні взяло участь 10 учителів початкової школи.

Проведене анкетування свідчить про обізнаність більшості вчителів (80\%) про нормативноправову базу організації освітнього процесу в НУШ. Однак 20\% з опитаних учителів відчувають труднощі під час складання робочих програм, реалізації компетентнісного підходу в навчанні, під час планування й організації дослідницької, самостійної та творчої діяльності учнів. 30\% 3 них відчувають труднощі у використанні нових профресійних ролей в умовах НУШ. Під час бесід вони відзначають складність відходу від репродуктивного навчання (за допомогою репродуктивного навчання діти отримують міцніші знання, вчителю легше готуватись, організувати й перевірити результати репродуктивного навчання), складність відмови від авторитарного стилю спілкування з учнями (легше підтримувати дисципліну, учні завжди погоджуються з учителем). Інші опитані учителі (70\%) таких труднощів не відчувають і зазначають, що й раніше виконували більшість з перерахованих ролей, оскільки переконані, що головне завдання сучасного вчителя - не дати дітям знання в готовому вигляді, а організувати їхню активну самостійну навчально-пізнавальну діяльність, організувати навчання в процесі активної діяльності, створити умови для самостійного вирішення учнями дослідницьких завдань (з відповідей учителів).

Необхідність реалізації нових профресійних ролей учителем в Новій українській школі вимагає відповідного оновлення змісту, форм і методів фрахової підготовки майбутніх учителів початкової школи. У Національному університеті «Чернігівський колегіум» імені Т.Г. Шевченка така підготовка здійснюється 3 урахуванням основних тенденцій ресрормування освіти, нових підходів, методик, технологій Нової української школи. Так, навчальні програми педагогічних навчальних дисциплін та фрахових методик, тематику курсових та кваліфрікаційних робіт, програми кваліфікаційних іспитів, програми педагогічних практик оновлено відповідно до основних тенденцій НУШ [5]. Значна увага приділяється підготовці майбутніх учителів до виконання різних професійних ролей у початковій школі. На лекційних і практичних заняттях студенти аналізують сутність та особливості нових професійних ролей учителя НУШ. Під час практичних занять з педагогічних навчальних дисциплін і методик викладання навчальних предметів у початковій школі студенти набувають здатності виконувати ці професійні ролі під час квазіпрофесійної діяльності. Наприклад, проводячи фррагмент розробленої ранкової зустрічі зі студентами групи, майбутні педагоги вчаться виконувати роль фасилітатора [2]. Під час проходження різних видів педагогічної практики майбутні вчителі спостерігають за реалізацією нових професійних ролей учителем, а також набувають власного досвіду в цьому напрямі.

Однак підготовка майбутніх учителів у досліджуваному напрямі потребує вдосконалення. На нашу думку, необхідним є збільшення кількості творчих завдань, використання нових фрорм організації діяльності студентів, тренінгів тощо. Це сприятиме усвідомленню, поглибленню знань майбутніх учителів щодо нових профресійних ролей в НУШ, а також формуванню їхньої здатності виконувати ці ролі під час власної педагогічної діяльності.

Висновки. Теоретичний аналіз показав, що у вчителя сучасної початкової школи з'явилися нові професійні ролі фрасилітатора, модератора, тьютора, коуча. Аналіз результатів проведеного анкетування серед учителів початкових класів показав загалом їхнє позитивне ставлення й готовність до виконання цих ролей. Однак значна частина вчителів відчуває труднощі у реалізації нових профресійних ролей, що зумовлює необхідність їхньої відповідної перепідготовки. Вивчення досвіду фрахової підготовки майбутніх учителів початкової школи свідчить про необхідність її вдосконалення у напрямі формування їхньої здатності до реалізації нових профресійних ролей в НУШ.

Перспективи подальших досліджень вбачаємо в розробленні та впровадженні в процес підготовки та перепідготовки вчителів початкової школи системи спеціальних завдань з фрормування здатності виконувати нові професійні ролі.

\section{БІБЛІОГРАФІЧНИЙ СПИСОК:}

1. Державний стандарт початкової загальної освіти. Київ, 2018. URL: https://www.kmu.gov.ua/ua/ npas/pro-zatverdzhennya-derzhavnogo-standartupochatkovoyi-osviti (дата звернення: 10.07.2019).

2. Лимар Ю.М. Підготовка майбутніх учителів до проведення ранкових зустрічей у початковій школі. Педагогічна освіта: теорія $i$ практика : збірник наукових праць / Кам'янецьПодільський національний університет імені Івана Огієнка ; Інститут педагогіки НАПН України / гол. ред. Лабунець В.М. Вип. 25 (2-2018). Ч. 2. Кам'янецьПодільський, 2018. С. 180-185. 
3. Мукан Н.В. Неперервна педагогічна освіта вчителів загальноосвітніх шкіл: професійне становлення та розвиток (на матеріалах Великої Британії, Канади, США) : монографрія. Львів : Вид. Львівської політехніки, 2010. 284 с.

4. Нові професійні ролі вчителя. URL: https://metoddialogu.blogspot.com/2017/11/blog-post 90.html (дата звернення: 12.07.2019).

5. Освітньо-профресійна програма. Початкова освіта та інформатика першого (бакалаврського) рівня вищої освіти за спеціальністю 013 «Початкова освіта» галузі знань 01 Освіта. Кваліфікація Бакалавр початкової освіти. Вчитель початкової школи : навчально-методичне видання / уклад. С.І. Стрілець,
Ю.М. Лимар, Н.М. Стрілецька. Чернігів : НУЧК імені Т.Г. Шевченка, 2018. 36 с.

6. Профресійне вдосконалення педагога у контексті концепції «Нової української школи». URL: https://naurok.com.ua/2018p. (дата звернення: 9.06.2019).

7. Сігаєва Л.Є. Розвиток освіти дорослих в Україні (друга половина XX ст. - початок XXI ст. : монографрія / за ред. С.О. Сисоєвої ; АПН України, Інститут педагогічної освіти і освіти дорослих АПН України. Київ : ТОВ ВД «ЕКМО». 2010. 420 c.

8. Шевчук І. «Нові ролі» педагога. Методичні діалоги : інтернет-газета Віньковецького РМК. URL: http://metoddialogu.blogspot.com (дата звернення: 12.06.2019). 